Journal of Humanities, Social and Management Sciences (JHSMS)

eISSN: 2788-4791 (online)

https://doi.org/10.47264/idea.jhsms/2.1.18

Vol. 2, No. 1 (January-June 2021), 214-232

https://www.ideapublishers.org/index.php/jhsms

Review Article

\title{
Impact of selected social welfare programs on poverty alleviation and health outcomes in Pakistan
}

\author{
Ilsa Tariq ${ }^{1} \mid$ Tehmina Aslam*2 | Muhammad Aurangzeb Khan ${ }^{3}$ \\ 1. Economics, Management and Social Sciences Program, London School of Economics \\ and Political Science (LSE), University of London, United Kingdom. \\ 2. School of Integrated Social Sciences, The University of Lahore, Lahore, Pakistan. \\ 3. Department of Social Work, Women University Swabi, Swabi, Pakistan. \\ *Corresponding Author Email: taranjha1@gmail.com
}

Published: November 29, 2021

\begin{abstract}
The purpose of this paper is to review and analyse poverty alleviation and health outcomes through the effectiveness of two major programs launched by the government to uplift social welfare in Pakistan (Benazir Income Support Program (BISP) and the Sehat Sahulat Program (SSP). We also aim to explore the link between poverty and health in light of the BISP and SSP. Secondary data is utilized to carry out this study, where qualitative data is gathered from the beneficiaries' interviews while quantitative data is based upon the poverty line. Through this study, we can conclude an overall positive impact of the BISP and SSP on two components of the Human Development Indicator (HDI) concerning poverty and health: standards of living and life expectancy. Although positive conclusions have been brought about by BISP such as a reduction in wasting (girls) and increased food consumption, it fails to substantially cover health and may even be ineffective if individuals face external shocks such as dangerous illnesses. Such findings strengthen the importance of the SSP as a social welfare program alongside the BISP to secure far more wholesome and successful outcomes. By exploring the interchangeable link between poverty and health and connecting it to these programs, we further assert the complimentary nature of the BISP and SSP and base our evaluation on it.
\end{abstract}

Keywords: Poverty, Health, Pakistan, Social welfare, SSN, UHC, SSP, BISP, HDI.

How to Cite: Tariq, I., Aslam, T., \& Khan, M. A. (2021). Impact of selected social welfare programs on poverty alleviation and health outcomes in Pakistan. Journal of Humanities, Social and Management Sciences (JHSMS), 2(1), 214-232. https://doi.org/10.47264/idea.jhsms/2.1.18

Publisher's Note: IDEA PUBLISHERS (IDEA Journals Group) stands neutral regarding jurisdictional claims in the published maps and institutional affiliations.

Copyright: (C 2021 The Author(s), published by IDEA PUBLISHERS (IDEA Journals Group).

Licensing: This is an Open Access article published under the Creative Commons AttributionNonCommercial 4.0 International License (http://creativecommons.org/licenses/by-nc/4.0/) 


\section{Introduction}

International organizations, governments, practitioners, and policy-makers measure poverty through various ways. It is a multidimensional concept comprising of economic, natural and social factors embedded within broader socio-political processes. "Poverty is pronounced deprivation in well-being," according to the World Bank (2000). 'Well-being' in itself can be referred to "the quality of the person's being" (Sen, 1992) or "whatever is assessed in an evaluation of a person's life situation or 'being"' (Gasper, 2002). An individual's life situation can be described by 'well-being'. Several measures of well-being have been devised with some particularly narrowed down to income (e.g., \$1/day poverty line of the World Bank in the 1990s) and consumption while others are broad enough to also include other dimensions of life (e.g., health and education). Some famous indicators are the HDI, put forward in the United Nations Development Programme (1990) and the Multidimensional Poverty Index (MPI) developed by Alkire and Foster (2011). Amartya Sen's Capability Approach inspired the idea of both, MPI and HDI in 1979. The capabilities approach also accentuates capturing perceptions of poor people as one of the most primal ingredients in measuring and understanding poverty (Sen, Amartya (1999)). Although a dilemma as grim as poverty diminishes as we progress through current times, it still stands as a pressing issue. Pakistan currently emerges as the fifth most populous country in the world and is projected to rank the third largest by the time the year 2050 would be incoming (Qureshi, 2020). While the country has good record in terms of economic growth, it still categorizes as one of the poorest countries in the world. However, poverty in Pakistan has fallen dramatically and improved in between the years 2001 and 2015 - reaching to $24.3 \%$ from $64.3 \%$, according to the World Bank.

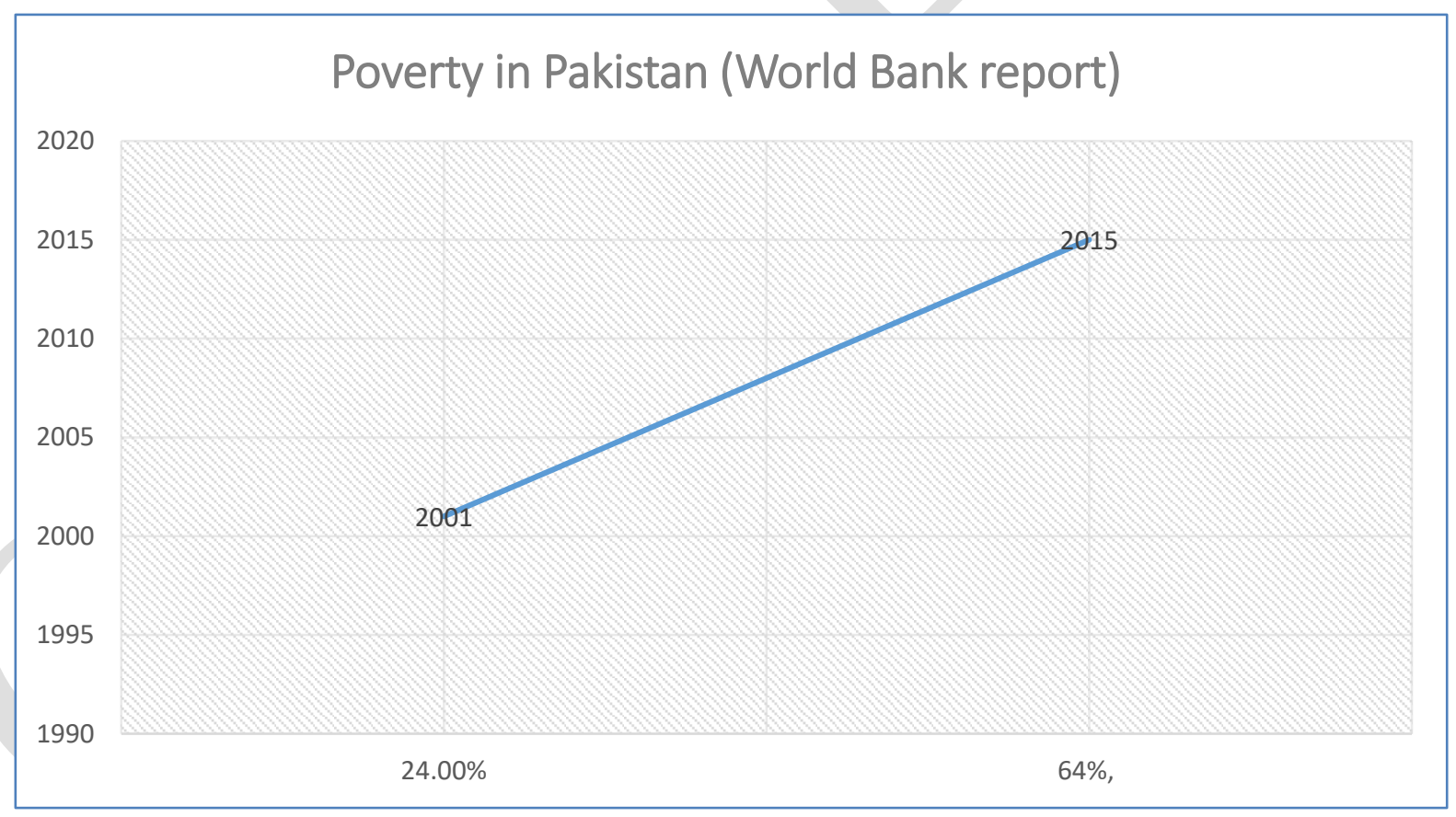

According to Haughton and Khandker (2009), one of the steps required to measure poverty include the establishment of a poverty line (GSDRC, 2016). In Pakistan, the poverty estimation methodology and poverty line were determined in 2001 which was based off the 1998-99 consumption data. Built upon the food energy intake (FEI) by using the Pakistan Household Integrated Economic Survey data, headcount poverty in Pakistan was estimated. As is the case 
Impact of selected social welfare programs on poverty alleviation and health outcomes ...

in many developing countries, headcount poverty in Pakistan is assessed using data from the Pakistan Household Integrated Economic Survey and the food energy intake (FEI) technique. On the basis of a threshold level of eating minimum $2350 \mathrm{kcal} /$ day, the Planning Commission assessed the official poverty line at Rs. 637.54 per person per month in 1998-99 pricing. Following that, the poverty levels were revised for each subsequent survey period to account for the impact of inflation between two survey periods. This technique regresses overall spending of the lowest $60 \%$ of the population on minimal calories $(2350 \mathrm{kcal} /$ day $)$ using the 1998-99 consumption basket.

Concerns about the FEI method is also widespread. The FEI approach, according to Ravallion and Bidani (1994), may be skewed towards particularly wealthy countries because to higher relative food costs and systematic variations in consumption patterns and activity levels between regions and survey years (e.g., towards urban areas relative to rural areas). Furthermore, this technique fails to account for the real impact of price rises. According to Ravallion (1998), an increase in prices can either raise or lower the poverty line, depending on how consumption habits evolve (normal versus inferior goods). The CBN method is an alternative to the FEI method (Ravallion, 1994; 1998; Ravallion \& Bidani, 1994; Ravallion \& Sen, 1996; Wodon 1997). In most cases, the CBN method discovers and analyses a single national consumption bundle that meets minimal calorie needs. Further in the paper, we will analyse the extent to which BISP's reduces poverty by FEI and CBN approaches.

Health can be considered as a resource supporting the functioning of an individual in wider society - providing the means to lead a purposeful and meaningful life. According to the World Health Organization (WHO), 'health' may be defined as, "a resource for everyday life, not the objective of living. Health is a positive concept emphasizing social and personal resources, as well as physical capacities." Education and literacy, culture, social environments, income and social status, health care services, biology and genetics and even social support networks are one of the few key factors influencing the health of individuals (Felman, 2020). To describe a population's health, life expectancy sprouts as an ideal measure - capturing mortality along the course of an individual's entire life, unlike child and infant mortality. Pakistan has weak health indicators in contrast to other countries, and its progress toward the Millennium Development Goals relating to health has been ineffectual (MDGs). The lack of an effective framework for healthcare finance is linked to the lack of progress toward achieving the MDGs. Healthcare spending on chronic and long-term illnesses is catastrophic, consuming a significant portion of household budgets and limiting people's ability to access basic services.

The HDI is a summary metric for analysing long-term progress in three essential elements of human development: living a long and healthy life, having access to information, good quality of living. Life expectancy is a measure of how long and healthy a person lives. Access to learning and knowledge is measured by expected years of schooling for children of schoolentry age, which is the total number of years of schooling a child of school-entry age may expect to receive if current patterns of age-specific enrolment rates remain constant throughout the child's life. Gross National Income (GNI) per capita is used to measure standards of living. GNI is expressed using purchasing power parity (PPP) conversion rates and represented in constant 2017 international dollars (United Nations Development Programme, 2020). In this paper, we are concerned with living standards and life expectancy, which BISP and SSP aim to enhance through relieving poverty and improving healthcare access. 


\subsection{Benazir Income Support Program (BISP)}

The BISP programme categorizes as one of the top programmes worldwide in terms of coverage and targeting (World Bank, 2018). The main objective of BISP is to lessen adverse impacts of food, fuel and financial crisis on the poor while its secondary objective gravitates towards increasing household investments in health and education (Cheema et al., 2015). Cash assistance has been provided to 5.8 million families (with a focus on women) by the programme with a quarterly stipend of Rs. 5000 (around 35 USD). The programme also focuses on assisting children from low-income families to complete their primary-level education. Up till now, 3.5 million children are enrolled, and their mothers receive an extra top-up of Rs. 750 per quarter for male children and Rs. 1000 per quarter for female children - holding the condition that the child would attend school, meeting the minimum attendance goal of 70\% (Iqbal et al., 2020).

For the eligibility of a BISP beneficiary, national parliamentarians carried out the initial identification of eligible households in their own constituencies (Cheema et al. 2015). This process changed with the introduction of the Poverty Scorecard (PSC) method of targeting being implemented for making the programme more effective. It was developed through usage of the Pakistan Social and Living Standards Measurement (PSLM-4) survey data of 2005-2006 by two teams from the World Bank. Key indicators such as education, household size, child status, toilet facilities and landholding base the PSC with its data acquired through conductions of house-to-house survey in 2010-2011. When the survey completed, a welfare status score for each household (0-100 scale) was generated by the PSC - on which a proxy means test (PMT) was applied (Nayab \& Farooq, 2014). Households below or at a scale of 16.17 were deemed eligible for a cask transfer (O'Leary et al., 2011). Initially, the eligible households would receive the payments through Pakistan Post - leading to monumental transaction costs. Such a process changed with $90 \%$ beneficiaries now receiving cash transfers through the BISP debit card - reducing acts of pilferage and increasing the programme's transparency (BISP, 2016).

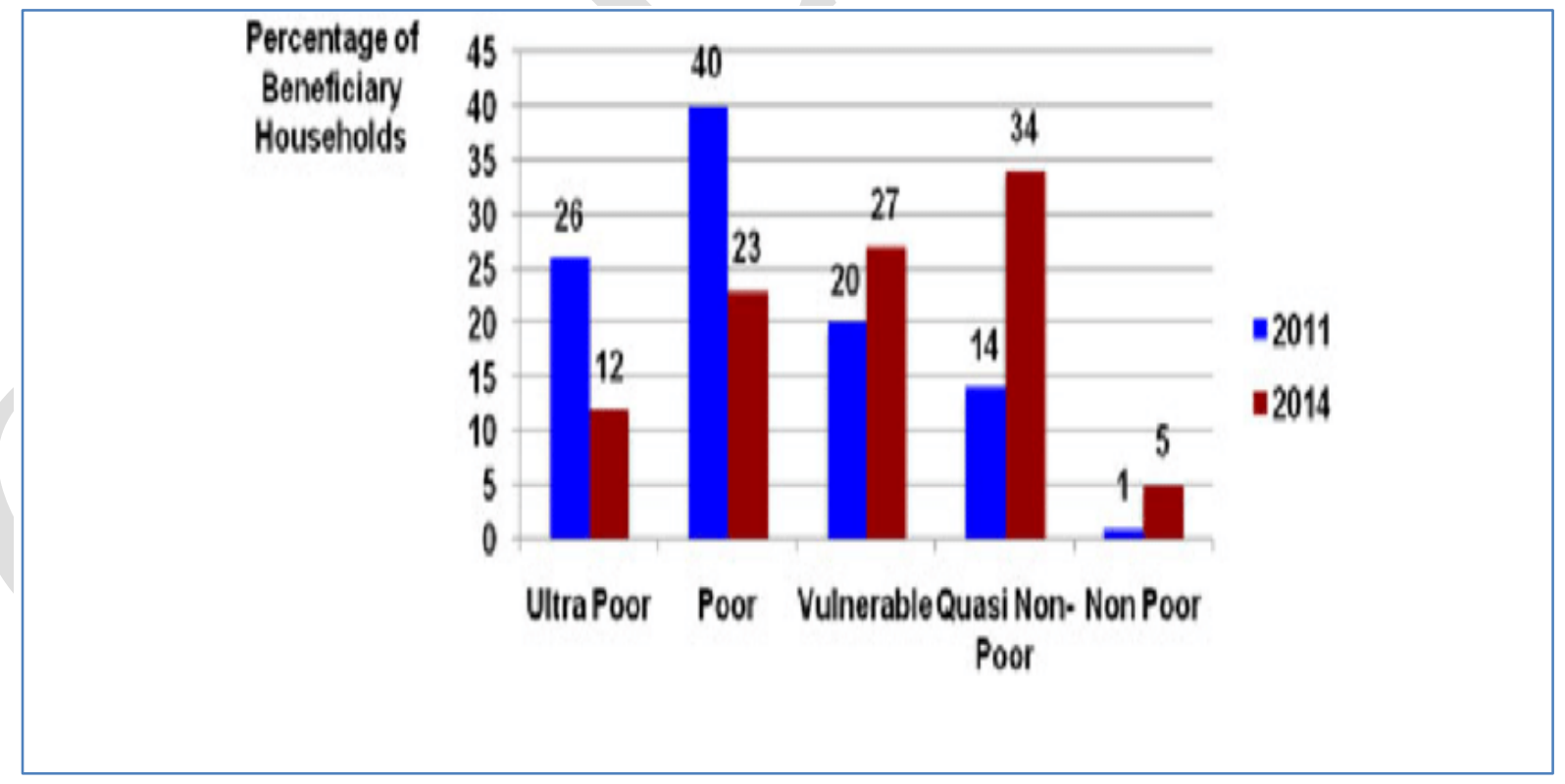

Source: ResearchGate

The core objectives of the BISP comprise of poverty and nutrition - initially designed with fulfilling the immediate objectives of preventing the downsides of food inflation on the poor 
Impact of selected social welfare programs on poverty alleviation and health outcomes ...

people. Furthermore, to prevent chronic and transient poverty, the program poses long-term objectives which provide a minimum income package to the poor.

If the FEI poverty line is used, we note that the current rate of poverty amongst BISP beneficiaries is $29 \%$ in the RD treatment group. Furthermore, BISP brings about a statistically significant and negative impact on the rate of poverty of -7 percentage points in the RD treatment group. There is weak evidence of an impact with a similar effect for KPK beneficiaries. Thus, with the FEI poverty line, there is frail evidence of lessening of the poverty gap with it being at $5 \%$ (Rs. 122).

However, in May 2016, the poverty line was calculated by using the CBN methodology, which would also include the cost of other essentials such as shelter, clothing and education (Finance Division of the Government of Pakistan, n.d.). An increase in the poverty line by 804 rupees (33\%) is noted with the CBN method. This means that it represents more than half of the transfer's monthly value. The current rate of poverty with the CBN methodology in the RD treatment group amongst BISP beneficiaries is to be way higher (64\%). A statistically significant, negative impact of -3 percentage points on the poverty gap for beneficiaries in the $\mathrm{RD}$ treatment group is also noted. Similar effects are noted in Punjab and KPK. Despite this, a $15 \%$ average poverty gap is noted for beneficiaries in the RD treatment group (equivalent to Rs. 496 per adult). With the CBN poverty line producing an average poverty gap of Rs. 496 and an average per adult equivalent monthly value of the transfer of Rs. 270 - it is impossible to bring a large number of beneficiaries above the poverty line.

Consequently, it can be said that there is no solid evidence of a reduction in the rate of poverty in terms of increasing consumption expenditure when utilizing the CBN poverty line as a reference. However, we do note an increase in the welfare of households through BISP. These findings are supported through qualitative research - showcasing beneficiaries using a portion of the BISP cash transfer to buy high-quality food and increase overall food consumption (OPM, 2016). A Male IDI from District Noshki, Balochistan reports,

"When the BISP money arrives, we stockpile food rations like wheat and pulses so that we may survive if we are unable to work for a few days. Also, because we have growing children in the family who want more food, we have begun to eat three times a day,"

A female IDI from District Bhawalnagar, Punjab says:

"When I go to get my BISP money, I purchase chicken and bananas. For all of us, it is a special day because the children know that their needs will now be met."

Indicators such as sanitation and sufficient health lack in beneficiary households. This is why, levels of stunting and wasting are classified as an ongoing crisis of child nutrition by the WHO. Stunting rates lie at $30 \%$ while wasting amounts to $15 \%$. In the beneficiary RD treatment sample, rates of wasting and stunting are at $18 \%$ and $44 \%$, respectively (OPM, 2016). A statistically significant, negative impact is noted on the proportion of girls wasted in RD treatment sample by BISP. Authors such as Duflo (2003) study the nutrition impact of programs like BISP on girls and boys - concluding a higher effect on girls under five. We also 
find no impact on the proportion of children undergoing an episode of diarrhoea in the past 30 days and the proportion of children who are completely vaccinated. This is based upon the impacts on child health indicators. So, it can be said that while child nutrition level still remains a concern, it has brought about reductions in wasting in girls. This supports the assertion that a reduction in poverty can certainly bring about an effect on health, as seen through improved quality of food brought into households and an improvement in wasting (girls).

\subsection{Sehat Sahulat Program (SSP)}

According to Ather and Sherin (2014), Pakistan possesses a population of 197 million people, 64 percent of whom reside in rural areas. Based upon the same research, Pakistan's healthcare system was primarily handled by the federal government until the 18th amendment, when the responsibility for administering the health-care system was handed to provincial governments. As a result, it has created a chance to implement systemic reforms in order to fulfil the goal of building a more equal health system.

According to economics genius Jeffery D Sachs, the goal of UHC is to respect each individual's right to health and minimize negative health spill overs from individuals to communities and from poor to rich countries (Khan \& Ayub, 2018). Thus, investing in the health of poor households benefit society as a whole. As a result of this well-known phenomenon, SSP holds potential for the entire population, even though it only covers half of it. The level of financial security provided by SSP is impressive as the beneficiary is not responsible for any coinsurance, co-payments, or premiums.

Increasing expenditure from general government income and/or foreign donor aid is generally used to close financial shortfalls. The reorganization of the health system entails giving the private sector a larger role in the provision of public services, with public sector assistance and supervision. This collection of information has been efficiently exploited by the SSP. Phase-II is completely funded by general government income, whereas Phase-I was significantly reliant on external funding, particularly from the German Development Bank. In addition, SSP recipients can use services from empanelled private hospitals for a set fee.

According to Dr. Shahid Younas (Hussain, 2019):

"Eradicating financial barriers is one of the objectives of the Sehat Sahulat Program... we are taking care of catastrophic health expenditure in the province, in a bid to extend financial protection to $69 \%$ of Khyber Pakhtunkhwa's population. Neglected transgender segments are also being included. So, efforts towards achieving Universal Health Coverage are clearly under way."

The initiative now only covers indoor patient care, but it will be expanded to include outdoor patient services in the future. The beneficiaries are chosen using a BISP-based survey that is cross-verified by the National Database and Registration Authority (NADRA) for members' household family tree at 32 PMT over the poverty line. According to authorities from the PMU, the SSP programme enrolled 59 percent of families in the country as of December 2019. In the combined districts of $\mathrm{AJK}, \mathrm{GB}$, and $\mathrm{KPK}$, however, the programme has virtually met its objective of $60 \%$ enrolment. A 97.5 percent satisfaction rating was found in a patient satisfaction survey (Ministry of Finance, Government of Pakistan, 2020). The implementing 
agency, State Life Insurance Company, ensures that beneficiaries are not duplicated across Federal territories (including combined districts) and KP.

The programme unveiled several success cases of patients across the country. Notable cases hail from Chakwal: six beneficiaries, coincidentally all women, have reported satisfaction in terms of affordability and quality ("State Health Stories", n.d.).
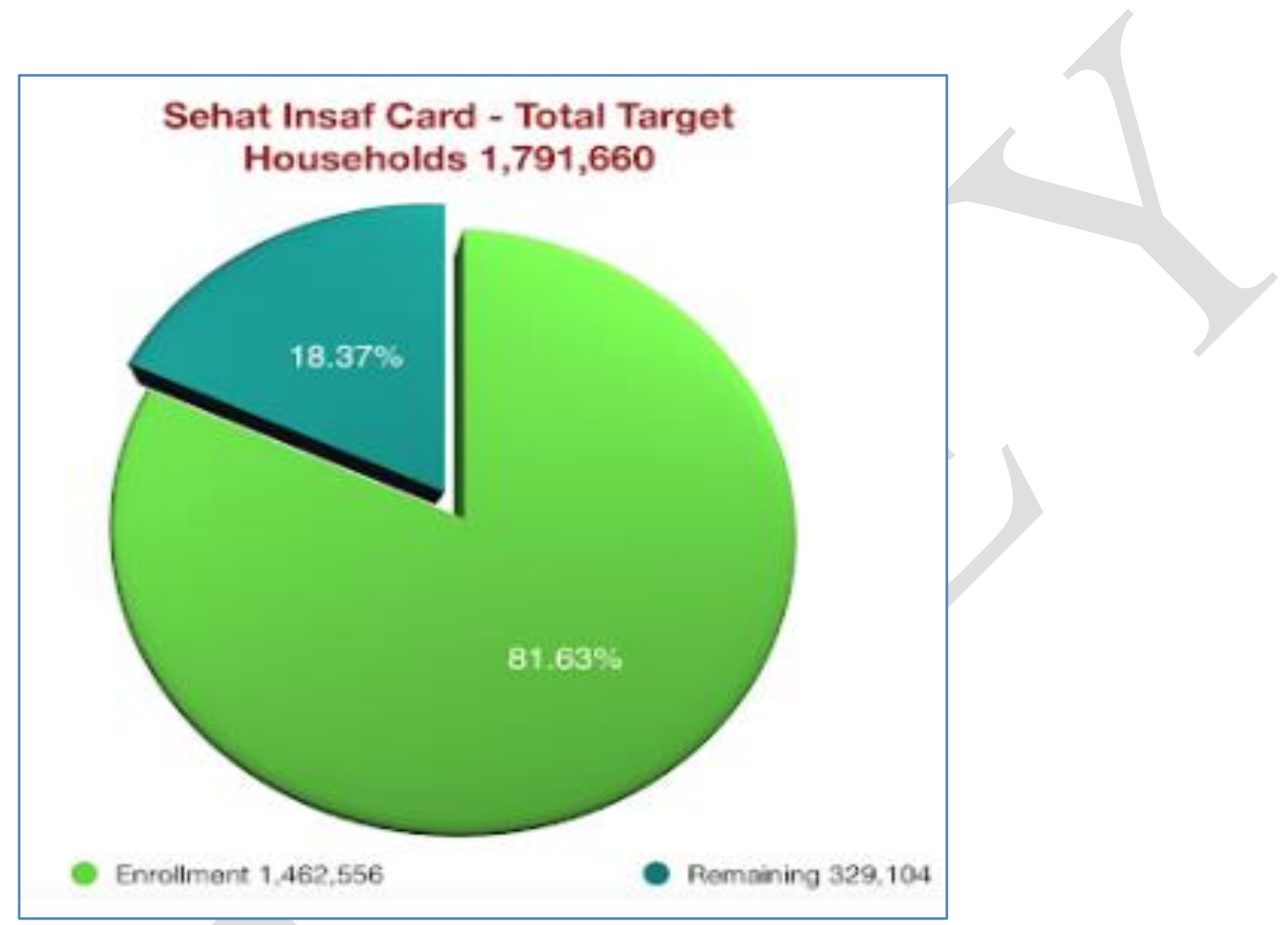

Source: Progress on Sehat Sahulat Program 25 June 2017

One such case includes that of Zenat Fatima, who has suffered from a paraumbilical hernia for the past ten years. Her spouse works as a labourer. The patient was in excruciating agony, but her spouse could not afford surgery. Fortunately, the family possessed the SSP - allowing them to receive cashless and free hospital treatments. After the procedure, the patient felt relieved and satisfied because of the costless treatment. Another beneficiary, Ghulam Sakina was diagnosed with fibroid uterus and recommended to undergo surgery. Her husband is also a labourer and unable to pay for her operation. She was informed of receiving free treatment through their Sehat-Sahulat card and went to the panel hospital. The surgery was provided at no cost, and they expressed gratitude for such excellent care. The remaining beneficiaries from Chakwal expressed similar positive results.

Based upon a survey carried out in two hospitals in Lahore (Azuhairi, \& Junaid, 2020), several favourable replies were obtained in response to the interview question on hospital healthcare service quality under the SSP. In this regard, one of the respondents stated:

"In my view, hospitals participating in the insurance programme cover all of the main components that any high-quality healthcare institution should provide, including facilities, access to all necessary services, environment, affordability, responsiveness, empathy, and care." 
According to the interviewee's statement, hospitals provide high-quality healthcare services to their patients through insurance programmes. Furthermore, based on the aforementioned statement, hospitals provide the same high-quality healthcare services to impoverished individuals as they do to those with a moderate or high income. The aforementioned response also suggests that the quality of healthcare services is meeting or exceeding patient expectations, resulting in increased satisfaction.

"Under the insurance programme, I was able to give some high-quality healthcare services, as the whole diagnosis procedure was smooth and wellexecuted. I found all of the healthcare staff to be quite knowledgeable, which aided in my rapid recovery."

The preceding comment from another responder, which is consistent with the prior response, also demonstrates the unparalleled quality of healthcare services. Patients obtain their desired healthcare outcomes under the insurance programme, and emerge content with the overall healthcare service, according to the respondent.

The interview's second question aimed to assess the insurance program's cost-effectiveness. One of the several responses stated:

"As a holder of the insurance card, I have been offered numerous free of charge healthcare treatments, which also cover a wide range of medical operations," one of the respondents noted. "I also feel that this card will be extremely useful to low-income individuals who are unable to handle their healthcare costs."

"Under the insurance scheme, I have supplied medical care valued up to 720,000 rupees," said another responder. "As a result, I am certain that the government's healthcare effort is both cost-effective and efficient."

The favorable replies from the interviewees imply that the SSP is extremely cost-effective, as it provides free medical operations like as brain surgery, angioplasty, and cancer treatment, in addition to regular medical check-ups. Normally, all of these medical procedures are quite expensive, which reflects the high cost-effectiveness of insurance card services such as the SSP. This supports the effect of health on poverty as beneficiaries have reported high costsavings without which their living expenditures could have been halted - driving them below the poverty line.

\section{Conceptual framework}

\subsection{Subjective well-being}

Subjective well-being (SWB) is a term that describes how individuals feel about themselves, their lives, and certain areas and activities in their life. For example, the term "happy" has been used to refer to both immediate and long-term appraisals of affect (Ed Diener, 2003). Researchers, legislators, national statistics agencies, the media, and the general public have all been more interested in information regarding SWB (also known as "self-reported wellbeing"). The importance of this data comes from its potential contribution to monitoring population 
Impact of selected social welfare programs on poverty alleviation and health outcomes ...

economic, social, and health problems, as well as guiding policy choices in these areas (Framework, Statistics, Education, Council, \& Stone, 2013).

It may also be described as overall assessments of one's pleasure with many aspects of one's life. Subjective well-being is defined in this study as an individual's pleasure or appraisal of these two initiatives in terms of their contribution to human well-being and quality of life. Furthermore, subjective well-being has a vital role to play in personal lives in order to accomplish its maximum operational potential, full of faith in the fulfilment of essential goals, and has the motivation and authority to consistently solve barriers in the life cycle.

\subsection{Community health benefits: Subjective well-being}

Community benefits are elaborated in the context of any result of activities for society in order to build an image, show others the unique characteristics, improve life, and share information/ideas of the local community, but we will discuss these benefits in terms of social assistance programmes for the population who were living below the belt of poverty (Akinwale, 2015) The provision of social assistance is one of the most significant ways that societies act to mitigate the negative consequences of socioeconomic deprivation (Faraz V Shahidi, 2019).

Government programmes that offer a minimum level of economic support to people and households living in poverty are referred to as social assistance. These programmes provide assistance in the form of direct cash transfers or in-kind benefits such as food stamps, health insurance, and rent subsidies. Social assistance has been proved to increase impoverished people's buying power and boost their living standards. In terms of public health, additional income can help people avoid dangerous exposures and embrace health-promoting behaviours. (Solar, 2010) As a result, theory predicts that social assistance programmes can help maintain the health of socioeconomically disadvantaged people while also reducing the severity of health disparities (Fritzell, 2014).

The social assistance programmes such BISP and SSP serve as a key medium for the individuals, since these efforts aim to alleviate poverty, they may enhance health outcomes by encouraging individuals to spend more on healthcare and increasing nutrition as a result of the greater quality and quantity of food accessible to households. Poverty has a negative impact on health. Furthermore, because of the impact of health on poverty, social security programmes like the SSP are just as important. As poor health may stifle economic opportunities, either due to a lack of alternatives due to physical or mental illnesses, or due to the high cost of healthcare treatments, which can lead to family poverty. As a result, poverty and health are inextricably linked (Olle Lundberg, 2008).

\subsection{Poverty elevation: Subjected well-being}

Poverty is defined as a lack of money and productive resources necessary for long-term survival. Hunger and malnutrition, restricted access to education and other basic services, social prejudice and marginalization, and a lack of involvement in decision-making are examples of its expressions. Poverty is borne disproportionately by certain socioeconomic groups (Hipsher, 2010a). 
Poverty alleviation is among the world's most pressing issues. Poverty is strongly linked to a slew of negative quantifiable characteristics of living standards, therefore eliminating poverty can improve the lives of millions of people all over the world. Examining examples from Asia may teach us a lot about poverty reduction since it is the region of the globe with both the most people living in poverty and the most success in decreasing poverty. (Hipsher, $2010 \mathrm{~b}$ )

Poverty is a state of deprivation as well as an unfavorable situation in which individuals are unable to appreciate the life that God has given them. Underemployment, incompetence, deprivation, instability, a lack of appropriate capital, facilities, and food to make a fair livelihood, as well as helplessness, are all characteristics. Poverty is one of the societal issues that not only harms society but also has an impact on the metropolis. Despite tremendous progress in boosting living standards in many countries in recent years, poverty remains a pervasive occurrence in the developing world, and it is still a difficult issue. (Pascale M. Joassart-Marcelli, 2008)

Economic activities must always be directed at providing a decent livelihood for a country's inhabitants so that they may live peacefully and contribute to the country's progress. Not only can growing growth rates help a country, but the trickle-down impact of national growth and development on the country's population may be even more important in terms of achieving equality for all citizens and eradicating poverty (Ghazala Yasmeen, 2011). As a case of Pakistan's income distribution, its uneven, resulting in class imbalance, poverty, and low human development, among other things. In some ways, it suffocates the country's general growth and development. Poverty is a severe concern to Pakistan since it expresses itself in a complicated web of difficulties such as illiteracy, economic inequality, lack of access to amenities, and ineffective policies, among others.

Interestingly, the influence of welfare programmes on a summary measure of a family's wellbeing, the family's poverty status, has received little attention. Presumably, one of the main goals of these two programmes, BISP and SSP, is to lower the poverty rate among low-income families along with that providing them the basic necessities of health These programmes are intended to protect the vulnerable poor and disadvantaged elements of society from livelihood issues, to provide financial assistance to the extreme poor through cash transfers, to enhance their social standing, to defend their rights, and to promote societal progress. In the event of economic threats, properly targeted and well managed social protection programmes and initiatives can reduce human capital loss, increase employment, and safeguard individuals from sliding into a vicious cycle of poverty. (Cook, 2010)

\section{Research methodology}

In this paper, secondary data is extracted for the purpose of analysing the effects of BISP and SSP on poverty and health and evaluating their effectiveness based on quantitative and qualitative data. In order to analyse the effectiveness of BISP, we strongly rely upon the Benazir Income Support Program: Final Impact Evaluation Report (Cheema, 2016) by Oxford Policy Management (OPM). The final evaluation study conducted by OPM was completed in 2016 - showcasing both quantitative and qualitative approaches to assess the impact of the BISP after five years of utilizing the PMT method. The study showed evidence that BISP led to an increase in monthly food intake in treatment homes, helping to reduce deprivations in the beneficiaries' living standards, using Regression Discontinuity Design (RD). We will explore 
Impact of selected social welfare programs on poverty alleviation and health outcomes ...

such findings in this paper by adopting the FEI and CBN poverty line, both. Furthermore, as presented in the final evaluation study, qualitative data through interviews with two beneficiaries have been also showcased in order to support the quantitative findings.

In the case of SSP, reliance upon qualitative data through thematic analysis drawn by interviews with patients from Chakwal and Lahore who have benefitted from the Sahulat-card. Such data has been gathered from the State Life Insurance webpage on beneficiaries in Chakwal and an existing research paper on the satisfaction and experience of clients from two hospitals in Lahore (A, A.A., \& Junaid, Arshad., 2020). Through these beneficiaries, we aim to form a conclusion by taking into account the cost-effectiveness and quality of healthcare services offered to the beneficiaries - particularly in Punjab.

Given the success of such research, there is some limitation that has been based on some factors. First, the time-period of both programs, BISP and SSP, are different. For example, results for BISP by the OPM study are based upon 2016, while data for SSP spans from 2016 to 2020 , which makes it slightly complicated to evaluate both initiatives on equal ground. Secondly, there is also some sort of restraining as the data collection for both programs was different from each other. Research on SSP is purely dependent upon qualitative data, whereas BISP encompasses quantitative aspects. Participants involved in taking the interviews summarized the questions carefully in the local language and translated them. Participants used the literal translation or metaphrase technique. Last, there is also a clash between the subject's locations as conclusions are drawn based upon beneficiaries in two cities of Punjab for SSP. At the same time, BISP data encompasses the whole of Pakistan.

\section{Analyses}

\subsection{Effect of health on poverty}

In the pre-modern, poor world, life expectancy at birth revolved around the 20s and 30s due to high child and infant mortality rates. Even those surviving childhood, life expectancy at the age of 15 meant just an added 30 years (Riley, 2001). During the Age of Enlightenment, life expectancy stretched and improved even more so in the early $19^{\text {th }}$ century amongst newly industrialized countries, whilst staying relatively lower in other parts of the world. This resulted in inequality in the manner by which health was apportioned across the globe. Good health persisted in richer countries while persistently bad health stuck up with poor countries (Green, 2018). However, the last few decades showcased decreasing global inequality with no country possessing a lower life expectancy than those with the topmost life expectancy in 1800. A more than double figure has been noted in the global average life expectancy since 1900 - now emerging above 70 years. As of 2019, Central African Republic stands as a country with the lowest life expectancy of 53 years while Japan hoards 30 more years.

An important question revolves around whether improvements in life expectancy has played an effect on poverty. Indeed, there are several authors who have argued that abysmal health of poor people acts as an obstacle to their ability to grow out of the clutches of poverty. For example, economist Jeffrey Sachs has long claimed the role malaria has played in hindering poverty reduction and development in sub-Saharan Africa (Sachs, 2005). Furthermore, Sach and others have also shown how individuals born after the eradication of malaria in certain countries (e.g., Colombia, Mexico, Sri Lanka and Brazil) display higher literacy and income 
rates compared to those born prior to the eradication. Similar evidence is extracted from the Great Leap Forward famine in China during the 1950s and 1960s as well as hookworm elimination in the USA (Bleakley, 2010). However, it is also worth noting that better health does not establish a relationship with lower poverty levels and economic growth at the country level (Acemoglu and Johnson, 2007; Packard, 2009).

\subsection{Effect of poverty on health}

Around 36 million people fall prey to non-communicable diseases such as cancer, diabetes, cardiovascular disease and chronic lung disease (World Health Organization, 2011). Both, viral and bacterial communicable diseases such as tuberculosis, malaria and AIDS/HIV are the most common - leading to millions of deaths annually. Another health issue is malnutrition - either causing death or branching out to other health problems predominantly in children. Young children under the age of five are most at risk and pass away from it. According to records, around 3.1 million children die as a result of malnutrition annually (UNICEF, 2018a). Hunger and malnutrition account for more than half of all child fatalities worldwide, as malnutrition makes children more susceptible to sickness and exacerbates disease (UNICEF, 2018a). The main reason for this boils down to the absence of means to purchase food. When we learn this, we realize how greater wealth may automatically result in individuals to spend a higher amount of money on health (particularly sanitation), nutrition and healthcare. Even evidence showcases a positive relationship between higher levels of life expectancy and higher levels of GDP per capita for developing countries (Deaton, 2013). However, a certain income level is reached when such a relationship flattens a little - indicating a rise in GDP per capita levels to be uncorrelated with an increase in life expectancy. This is represented through the Preston curve - introduced by Samuel Preston in 1975 (Green, 2018).

\subsection{Social welfare programs: BISP and SSP}

SSNs (such as BISP) may improve health outcomes as it aims to relieve poverty - prompting people to spend more on healthcare and improving nutrition due to higher quality and quantity of food available for households (effect of poverty on health). Moreover, social security programs such as the SSP are also just as essential because of the effect of health on poverty. The poor health, as we have explored above, can drive away the economic prospects either owing to limited options due to the physical/mental ailments, or expensive healthcare treatments which may sprout poverty in households. Hence, poverty and health are intertwined from both ends.

SSNs in Pakistan have been riddled with many issues (Khan \& Qutub, 2010). The first category of the social protection program introduced in the country in the 1950s included the old age benefits institution, the workers' welfare fund and the employees' social security scheme, which only catered to people employed in the formal sector and the retired labor force with nil coverage of the informal sector and agricultural labour forces - comprising $67 \%$ of the entire labour force (Khan \& Qutub, 2010).

Cash assistance programs such as Pakistan Bait-ul-Mal, Zakat and many other public works programmes consisted of the second category of social protection programs which were designed to cover the vulnerable and poor (Khan \& Qutub, 2010). Both such categories have been fragmented, possessed low budgets, lacked proper design and implementation and had 
Impact of selected social welfare programs on poverty alleviation and health outcomes ...

scarce impact (World Bank, 2007). This led to the establishment of the BISP in 2008, after forming the Social Protection Policy (NSPP) in 2007 following the foundation of the poverty reduction strategy paper (PRSP) in 2001.

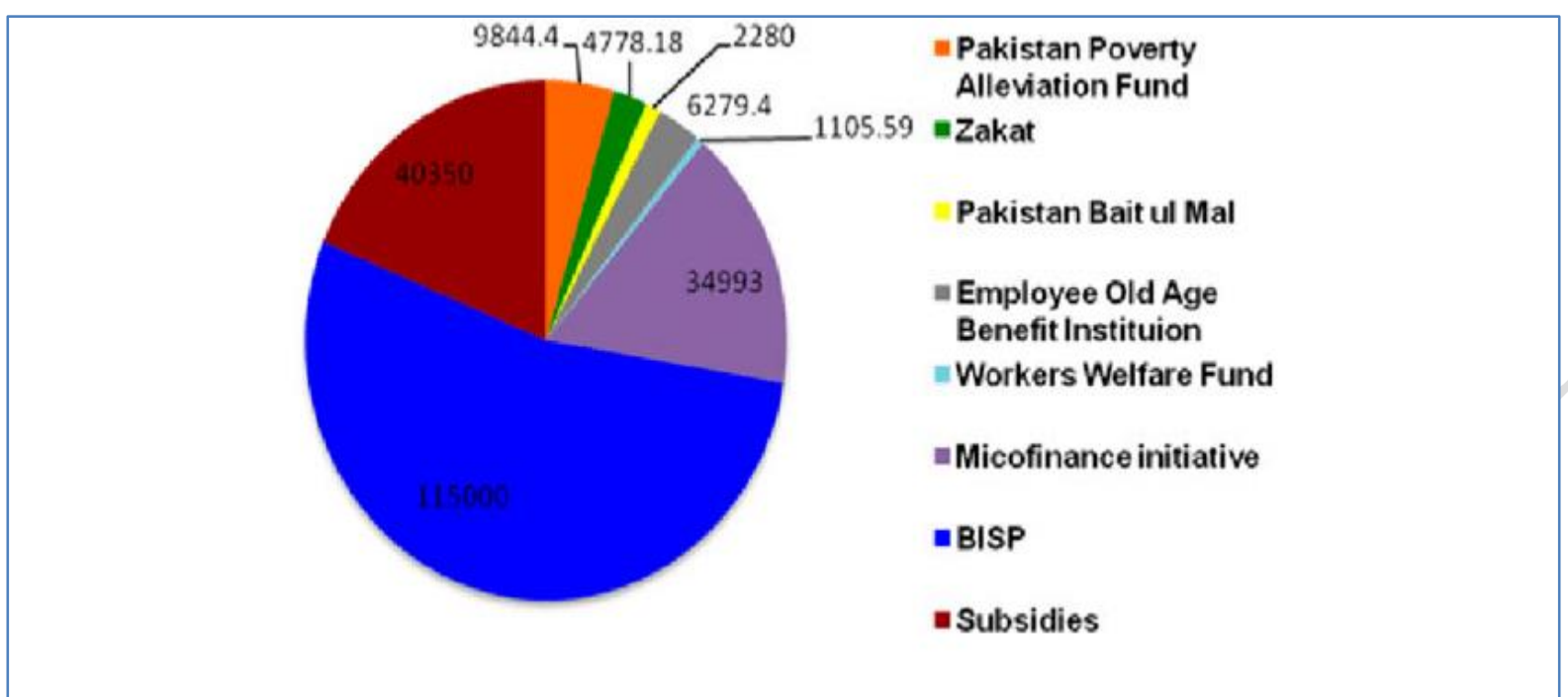

Source: ResearchGate

Child nutrition levels remain a concern as levels of stunting and wasting represent an emergency. Wasting or thinning suggests a recent and significant weight loss process, which is frequently linked to acute hunger and/or severe illness. Stunted growth is defined as the inability to attain linear growth potential as a result of poor health and/or dietary circumstances. Stunting is linked to low socioeconomic conditions, and a reduction in the stunting rate is typically indicative of a country's overall socioeconomic situation improving (WHO, 2016). In Pakistan, around four out of ten children under the age of five are stunted (Junaidi, 2020). We are particularly interested in the role of BISP to attempt to contribute to children's health in regard to stunting.

The government has also made steps to introduce improvements to Pakistan's healthcare system by launching the SSP in the province of KP. It is a pro-poor policy that benefits $51 \%$ of the (poorest) people of KP. Introduced in 2016, the major purpose of the SSP is to improve the health of the target population (households below the poverty line) by increasing access to high-quality healthcare services and to reduce poverty by lowering out-of-pocket health-care spending. Over seven million households are registered in the programme, gaining access to high-quality medical treatment costing approximately 720,000 Pakistani rupees (PKR) (approximately 4600 USD) per family per year from both public and private specialist tertiary care and specialty institutions. In response to COVID-19, KP began a UHC programme for all of its 40 million people on August 21, 2020. This acted as a six-phased programme that concluded on $31^{\text {st }}$ January 31, 2021, making it Pakistan's first UHC programme to cover $100 \%$ of the population. It covers a variety of services, including emergency and maternity care, orthopaedic and general surgery, cardiac, neurological, and kidney disorders, diabetes, breast cancer screening, artificial limbs (prosthesis), cancer therapy, kidney transplant, and ICU care. These models were built in accordance with Pakistan's aim to attain universal health coverage by 2030 (Hussain \& Arif, 2021). For greater access to healthcare, insurance plans under UHC can play a key role by incorporating quality assurance into corporate procurement procedures. 
SSP has now been adopted in other provinces as well such as Punjab (World Health Organization, 2019). We will explore its effect on the lives of beneficiaries within two cities in Punjab (Chakwal and Punjab) and tie in our conclusions to uplifting poverty.

\section{Discussion}

According to Saeed and Hayat (2020), evidence displays economic growth leading to poverty reduction. This assertion is supported by several cross-regional and cross-country studies (Dollar and Kraay, 2002; Besley and Burgess, 2003; Ravallion and Chen, 2007). If that is the case, the need of cash transfers (SSNs) or direct redistribution is questioned. Since the advantages of growth are not held by everyone, especially the poorest, cash transfers are justified. Furthermore, through effective targeting, cash transfer programs as widespread as the BISP can reach the poor in a way that is advantageous to them (Fiszbein et al., 2009).

Since we have established a link between poverty and health - funding towards the health sector requires a clear vision in order to offer financial security and act as an effective way of improving equal access to high-quality health care for all. More resources should be spent in the health sector, and those resources should be used in the most cost-efficient manner possible to guarantee that everyone has effective access to a defined set of benefits/entitlements of high quality. The strategy of 'progressive universalism' has been defined as a set of entitlements and guaranteeing effective access for all through fair and sustainable prepayment arrangements. While Pakistan's budgetary situation is uncertain in the near to medium term, the federal and provincial governments have announced their intention to boost the health spending to $3 \%$ of GDP by 2023. This indicates a rising government commitment to supporting the health sector, which is critical given Pakistan's present extremely low levels of public spending on health and the requirement for a preponderance of the public funding for the health services in order to achieve UHC.

\section{Conclusion}

The BISP cash transfer has improved welfare in certain aspects of poverty by offering financial security through alleviating consumption-based poverty, as explored through the views of the beneficiaries. This brought about a difference in the lives of beneficiaries and even reduced wasting in girls. However, it is insufficient to bring the average beneficiary to this newly defined minimum level of income that would allow them to secure the basic necessities of life, as it has had unsatisfactory effects in improving health outcomes at both, programme and national levels (with the exception of child stunting, where it increased at the national level but reduced at the programme level). There is a substantial body of research suggesting that people who are slightly over the poverty line may only remain there for a short time and may fall back into poverty when they are subjected to a range of external shocks, which could be adverse health issues relying upon treatment. Hence, the newly introduced SSP compliments the BISP - standing as a successful social welfare program advancing health, which in turn may alleviate poverty due to its commitment to UHC. This led families to focus on basic necessities (such as food) rather than worrying about meeting the healthcare expenses. Thus, we have shown the link between poverty and health and how effective programs like the BISP and the SSP are required to ensure that both factors (poverty and health) are maintained and satisfy the components of HDI. 
Impact of selected social welfare programs on poverty alleviation and health outcomes ...

\section{Recommendations}

a) BISP continues to grow and offers an increment in the stipend to beneficiaries (The News, 2020) which would certainly increase food consumption; but other factors such as immunization, sanitation, maternal health care and access to safe drinking water strongly influence child nutrition outcomes (health) and stand just as significant. To promote beneficiaries' overall well-being and nutrition, social protection programmes and policies across the world are increasingly incorporating components related to food security, health, education, gender, and WASH. Furthermore, programme designs that include nutrition teaching and promotion, establish links with health services, and prioritize women are likely to improve nutrition indicators (FAO, 2015b). The BISP might be a feasible route for addressing all these child nutrition outcomes, and it could be modelled after existing social protection programmes that directly target the same issue, such as conditional cash transfers for health or behavioural change messages, for example.

b) In the SSPs and SHP initiatives, there are a number of design elements that need to be improved if they are to have a greater impact on the health system's efficiency, equity, and quality, and thus its sustainability, when scaled up. Benefits and conditions of access under the schemes, for example, must be established in a way that supports and encourages preventive and primary care, and payment methods must be further developed to remove possible supplier-induced demand and cost control. Integration of the different social health protection projects across the country should be seriously considered - at least functionally. Given that the schemes in KP and Punjab are nearly identical in design to the federal SSP, this might be accomplished in the near future. This will assure the long-term coherence of these efforts, which is important for improving fairness and efficiency across the country. Even as the SHP schemes are scaled up, the success of these initiatives will be dependent on a better use of the majority of public health spending - primarily funded through inputbased budgetary spending by provincial governments and is required to fund human resources for health, capital expenditure on health facilities and equipment, and medicine maintenance. Evaluation of provincial level efforts, such as programme-budgeting in Punjab and the People's PHC Initiative (PPHI) in Sindh Province, is a good place to start when it comes to reforming and changing Pakistan's health finance system toward UHC.

\section{References}

Acemoglu, D., \& Johnson, S. (2007). Disease and Development: The Effect of Life Expectancy on Economic Growth. Journal of Political Economy, 115(6), 925-985. https://doi.org/10.1086/529000

Arndt, C., \& Tarp, F. (2016). Measuring poverty and wellbeing in developing countries (p. 124). Oxford University.

Ather, F., \& Sherin, A. (2014). Health System Financing in Pakistan: Reviewing Resources and Opportunities. Khyber Medical University Journal, 6(2). https://www.researchgate.net/publication/266386279_HEALTH_SYSTEM_FINAN CING_IN_PAKISTAN_REVIEWING_RESOURCES_AND_OPPORTUNITIES.

Azuahairi, A. A., \& Arshad, J. (2020). Clients' Experience and Satisfaction of Utilizing Healthcare Services in a Community Based Health Insurance Program in Lahore, Pakistan. International Journal of Public Health and Clinical Sciences, 7(1), 105- 
106.

http://www.publichealthmy.org/ejournal/ojs2/index.php/ijphcs/article/view/1146

Bleakley, H. (2010). Health, human capital and development. Annual Review of Economics, 2, 283-310. https://doi.org/10.1146/annurev.economics.102308.124436

Cheema, I., Hunt, S., Javeed, S., Lone, T., \& O'Leary, S. (2016). Benazir Income Support Programme: Final Impact Evaluation Report (pp. 46-51). Oxford Policy Management.https://www.bisp.gov.pk/SiteImage/Misc/files/BISP_EvaluationRepor t Ver\%20without_FINAL.pdf

Cheema, I., Farhat, M., Hunt, S., Javeed, S., Pellerano, L., \& O'Leary, S. (2014). Benazir Income Support Programme: First follow up impact evaluation report. Oxford Policy Management.

Cheema, I., Farhat, M., Hunt, S., Javeed, S., \& O’Leary, S. (2015), Benazir Income Support Programme: Second impact evaluation report. Oxford Policy Management.

Deaton, A. (2013). The Great Escape: Health, Wealth, and the Origins of Inequality (pp. 59126). Princeton University.

Duflo, E. (2003). Grandmothers and Granddaughters: Old-Age Pensions and Intrahousehold Allocation in South Africa. The World Bank Economic Review, 17(1), 2. https://doi.org/10.1093/wber/lhg013

Felman, A. (2020). What is health? Defining and preserving good health. https://www.medicalnewstoday.com/articles/150999.

Food and Agriculture Organization of the United Nations. (2015). Social protection and agriculture: breaking the cycle of rural poverty (pp. 64-68). Rome: Food and Agriculture Organization of the United Nations. https://www.fao.org/3/i4910e/i4910e.pdf

Finance Division, Government of Pakistan. Pakistan Economic Survey 2015-16: Annexure III, Poverty (p. 283). Islamabad: Government of Pakistan.

Glinavos, I. (2006). The End of Poverty: How We Can Make It Happen in Our Lifetime by Jeffrey D. Sachs. The Economics of Transition, 14(3), 575-577. https://doi.org/10.1111/j.1468-0351.2006.00262.x

Goal 1. Eradicate extreme Poverty and Hunger-Millennium Campaign. Web.archive.org. https://web.archive.org/web/20061209131507/http:/www.millenniumcampaign.org/ site/pp.asp?c=grKVL2NLE\&b=185518.

Green, E. (2018). Poverty and development (pp. 61-66). University of London.

GSDRC. (2016). Poverty and Inequality (p. 6). University of Birmingham. https://gsdrc.org/wp-content/uploads/2016/06/PovertyInequalityTG.pdf

Hussain, R., \& Arif, S. (2021). Universal health coverage and COVID-19: recent developments and implications. Journal of Pharmaceutical Policy and Practice, 14(1), 2-3. https://doi.org/10.1186/s40545-021-00306-X

Iqbal, T., Padda, I., \& Farooq, S. (2020). Sustainable impacts of social safety nets: The Case of BISP in Pakistan. Pakistan Journal of Applied Economics, 30(2), 154. http://www.aerc.edu.pk/wp-content/uploads/2021/01/Paper-975-TEHMEENAIQBAL-I.pdf.

Hussain, H. (2019). Understanding Pakistan's efforts to align quality healthcare with Sustainable Development Goals [Blog]. Retrieved 21 June 2021, from https://blogs.lse.ac.uk/southasia/2019/10/28/understanding-pakistans-efforts-toalign-quality-healthcare-with-sustainable-development-goals/.

Junaidi, I. (2020). 40pc children under five years stunted in Pakistan: report. Dawn News. Retrieved 18 July 2021, from https://www.dawn.com/news/1586121. 
Impact of selected social welfare programs on poverty alleviation and health outcomes ...

Khan, S., \& Ayub, A. (2018). Progress of Khyber Pakhtunkhwa (Pakistan) Towards Universal Health Coverage. J Ayub Med Coll Abbottabad,30(1), 484. https://www.researchgate.net/publication/329153636_Progress_Of_Khyber_Pakhtu nkhwa_Pakistan_Towards_Universal_Health_Coverage.

Khan, S., \& Ayub, A. (2018). Progress Of Khyber Pakhtunkhwa (Pakistan) Towards Universal Health Coverage. J Ayub Med Coll Abbottabad,30(1), 484. https://www.researchgate.net/publication/329153636_Progress_Of_Khyber_Pakhtu nkhwa_Pakistan_Towards_Universal_Health_Coverage.

McGillivray, M. (2007). Human Well-Being (pp. 23-64). Palgrave Macmillan.

Ministry of Finance of the Government of Pakistan. (2020). Health and Nutrition (p. 218). Islamabad: Government of Pakistan.

Ravallion, M., \& Bidani, B. (1994). How Robust Is a Poverty Profile? The World Bank Economic Review, 8(1), 75-102. https://doi.org/10.1093/wber/8.1.75

Nayab, D., \& Farooq, S. (2014). Effectiveness of Cash Transfer Programmes for Household Welfare in Pakistan: The Case of the Benazir Income Support Programme. The Pakistan Development Review, 53(2), 145-174. https://doi.org/10.30541/v53i2pp.145-174

Packard, R. (2009). Roll Back Malaria, Roll in Development? Reassessing the Economic Burden of Malaria. Population And Development Review, 35(1), 53-87. https://doi.org/10.1111/j.1728-4457.2009.00261.x

Qureshi, Z. (2020). Pakistan surpasses Brazil to become world's 5th most populous country. Gulf News. https://gulfnews.com/world/asia/pakistan/pakistan-surpassesbrazil-to-become-worlds-5th-most-populous-country-1.72557051.

Roser, M., Ortiz-Ospina, E., \& Ritchie, H. (2021). Life Expectancy. Our World in Data. https://ourworldindata.org/life-expectancy.

Ravallion, M., \& Sen, B. (1996). When Method Matters: Monitoring Poverty in Bangladesh. Economic Development and Cultural Change,44(4), 761-792. https://doi.org/10.1086/452244

Riley, J. (2001). Rising life expectancy: A Global History (pp. 1-31). Cambridge University.

Sen, Amartya. (1999) Development as Freedom (pp. 366), New York: Knopf.

Saeed, M., \& Hayat, M. (2020). The Impact of Social Cash Transfers on Poverty in PakistanA Case Study of Benazir Income Support Programme. https://mpra.ub.unimuenchen.de/99805/.

The News. (2019). BISP stipend being increased to $R s$ 6,000: Dr Sania Nishtar. https://www.thenews.com.pk/print/600920-bisp-stipend-being-increased-to-rs-6000-dr-sania.

The News. (2020). BISP stipend being increased to Rs 6,000: Dr Sania Nishtar. https://www.thenews.com.pk/print/600920-bisp-stipend-being-increased-to-rs-6000-dr-sania.

UNICEF. (2018a). Malnutrition rates remain alarming: stunting is declining too slowly while wasting still impacts the lives of far too many young children. http://data.unicef.org/topic/nutrition/malnutrition/\#.

United Nations Development Programme. (2020). The Next Frontier: Human Development and the Anthropocene (p. 2). United Nations Development Programme. http://hdr.undp.org/sites/default/files/Country-Profiles/PAK.pdf

World Bank. (2000). Chapter 1: The Nature and Evolution of Poverty (p. 15). The World Bank. https://documents1.worldbank.org/curated/en/230351468332946759/pdf/226840W DR00PUB0ng0poverty0200002001.pdf 
World Health Organization. (2019). Pakistan Health Financing System Review 2019 (pp. 4-5). World Health Organization. https://phkh.nhsrc.pk/sites/default/files/202107/Pakistan\%20Health\%20Financing\%20System\%20Review\%20WHO\%202019.p $\underline{\mathrm{df}}$

World Health Organization. (2011). Global status report on noncommunicable diseases 2010 (p. 9). https://www.who.int/nmh/publications/ncd_report_full_en.pdf

Wodon, Q. (1997). Food energy intake and cost of basic needs: Measuring poverty in Bangladesh. The Journal of Development Studies, 34(2), 66-101. https://doi.org/10.1080/00220389708422512

Cook, N. K. (2010). Barriers to the Extension of Social Protection: Evidence from Asia. $\begin{array}{llll}\text { Institute of Developmen } & \text { Studies, }\end{array}$ https://bulletin.ids.ac.uk/index.php/idsbo/issue/view/42

Ed Diener, S. O. (2003). Personality, Culture, and Subjective Well-Being: Emotional and Cognitive Evaluations of Life. Annual Reviews. https://doi.org/10.1146/annurev.psych.54.101601.145056

Faraz V Shahidi, C. R.-E. (2019). The impact of social assistance programs on population health: A systematic review of research in high-income countries. BMC Public Health, 19(2). https://doi.org/10.1186/s12889-018-6337-1

Framework, P. O. B. R., Statistics, C. O., Education, D. O., Council, N. R., \& Stone A. A., M. C. (2013). Subjective Well-Being: Measuring Happiness, Suffering, and Other Dimensions of Experience. National Academic Press. https://www.nap.edu/catalog/18548/subjective-well-being-measuring-happinesssuffering-and-other-dimensions-of\#

Fritzell, K. (2014). Welfare states and population health: The role of minimum income benefits for mortality. Science Direct. https://doi.org/10.1016/j.socscimed.2014.04.029

Ghazala Yasmeen, R. B. (2011). Human development challenges and opportunities in Pakistan: Defying income inequality and poverty. Journal of Business Studies Quaterly, 2(3). http://citeseerx.ist.psu.edu/viewdoc/download?doi=10.1.1.653.1380\&rep=rep1\&typ $\underline{\mathrm{e}=\mathrm{pdf}}$

Hipsher, S. A. (2010). Private sector's role in poverty reduction. https://www.sciencedirect.com/topics/social-sciences/poverty-alleviation

Akinwale, O. P. J. O. (2015). The benefits of using a community-engaged research approach to promote a healthy lifestyle in three Nigerian urban slums. Southern African Journal of Infectious Diseases. https://www.tandfonline.com/doi/abs/10.1080/23120053.2014.11441558

Olle Lundberg, M. А. (2008). The role of welfare state principles and generosity in social policy programmes for public health: an international comparative study. The Lancet. https://doi.org/10.1016/S0140-6736(08)61686-4

Pascale M. Joassart-Marcelli, J. A. (2008). Fiscal Consequences of Concentrated Poverty in a Metropolitan Region. Annals of the Association of American Geographers. https://doi.org/10.1111/j.1467-8306.2005.00463.x

Solar, O. \&. (2010). A Conceptual Framework for Action on the Social Determinants of Health. Discussion Paper. WHO Document Production. World Health Organization. https://doi.org/10.13016/17cr-aqb9 